PRACE GEOGRAFICZNE

zeszyt 151, 2017, 121-132

doi: 10.4467/20833113PG.17.025.8037

Instytut Geografii i Gospodarki Przestrzennej UJ

Wydawnictwo Uniwersytetu Jagiellońskiego

\title{
BADANIE STREFY AERACJI \\ NA STANOWISKU LIZYMETRYCZNYM \\ PRZY POMOCY PENETRACYJNEGO \\ PROFILOWANIA OPORNOŚCI ELEKTRYCZNEJ
}

\author{
Anna J. Żurek, Wtodzimierz J. Mościcki
}

\section{Application of penetrometer-based electrical resistivity profiling to study the unsaturated zone in a lysimeter experiment}

Abstract: Knowledge about water flow and contaminant transport in the unsaturated zone is crucial for groundwater resource estimations and groundwater vulnerability assessments. Large field lysimeters are commonly used as physical models of the unsaturated zone. Tracer experiments conducted in lysimeters are generally applied to investigate the time scale of leaching processes in the unsaturated zone. In this paper the preliminary results of using penetrometer-based electrical resistivity profiling to follow tracer transport through the soil in a lysimeter. The measurements were made in two lysimeters (Liz A and Liz I) filled with the same sandy soil. A tracer solution was injected only into lysimeter A. The measurements in lysimeter I were treated as a benchmark reflecting the influence of temporal soil moisture variations on the soil electrical resistivity. Additionally, temperature profiling in the soil next to lysimeter column was conduceted to consider the impact of the temperature fluctuations on soil resistivity. The obtained soil resistivity profiles for lysimeter A clearly reflect the tracer breakthrough curves in the 7 th and 22nd day after injection. The analysis of the curves yielded the approximated velocity of tracer transport.

Keywords: lysimeter, tracer experiment, penetrometer-based electrical resistivity profiling 
Zarys treści: Rozpoznanie procesów przepływu wody i migracji zanieczyszczeń w strefie aeracji ma istotne znaczenie w szacowaniu zasobów wód podziemnych i ocenie ich podatności na zanieczyszczenie. Lizymetry o dużych rozmiarach są powszechnie stosowanymi modelami fizycznymi strefy aeracji. Eksperymenty znacznikowe realizowane w lizymetrach służą ocenie czasu przesączania przez strefę aeracji. W pracy przedstawiono wstępne rezultaty wykorzystania metody penetracyjnego profilowania opornościowego (PPO) do monitorowania procesu przemieszczania się znacznika w kolumnie lizymetru. Pomiary zostały wykonane w dwóch lizymetrach (Liz A i Liz I) wypełnionych tym samym gruntem piaszczystym. Iniekcji znacznika dokonano jedynie w lizymetrze A. Pomiary w lizymetrze I zostały potraktowane jako reperowe, oddające wpływ zmian wilgotności gruntu na jego oporność. Dla potrzeb uwzględnienia ewentualnego wpływu temperatury na pomiary oporności wykonano profilowanie temperaturowe w gruncie bezpośrednio przy lizymetrze. Uzyskane wykresy zmienności oporności w gruncie wypełniającym lizymetr A wyraźnie obrazują krzywe przejścia znacznika po 7 i 22 dobach od iniekcji. Pozwoliło to na przybliżoną ocenę prędkości przesączania znacznika.

Stowa kluczowe: lizymetr, eksperyment znacznikowy, penetracyjne profilowanie opornościowe

\section{Wprowadzenie}

Procesy zachodzące w strefie aeracji mają istotne znaczenie w procesie formowania się zasobów wód podziemnych, zarówno w aspekcie ilościowym, jak i jakościowym. Na intensywność procesu infiltracji w obszarach zasilania wpływa głównie przepuszczalność utworów strefy przypowierzchniowej oraz wysokość opadów, natomiast o prędkości przepływu wody w strefie nienasyconej decyduje rozkład wilgotności w jej profilu (Szymkiewicz 2013). Rozkład ten jest zmienny w czasie i ściśle powiązany z przebiegiem zdarzeń opadowych.

W trakcie procesu infiltracji, wskutek naturalnego procesu interakcji ze skałami występującymi w strefie aeracji, zmianie ulega skład chemiczny wód opadowych. Wody te są z reguły wodami ultrasłodkimi o bardzo niskiej mineralizacji i stanowią doskonały rozpuszczalnik dla wielu substancji występujących w środowisku wód podziemnych. Intensywność procesów transformacji składu chemicznego wody infiltrującej zależy przede wszystkim od składu mineralnego osadów oraz od czasu przesączania się wody przez strefę aeracji.

Wraz z infiltrującą wodą może mieć miejsce także migracja zanieczyszczeń z powierzchni terenu do strefy saturacji. Spośród substancji rozpuszczonych w wodzie najszybciej migrują zanieczyszczenia trwałe poruszające się z prędkościami zbliżonymi do prędkości przepływu wody. Ocena prędkości migracji takich zanieczyszczeń w strefie aeracji jest niezbędna w opracowaniach dotyczących zagadnień ochrony wód podziemnych.

Złożoność procesów przepływu wody i migracji zanieczyszczeń w strefie aeracji analizuje się na modelach fizycznych tej strefy, z których najpopularniejsze są lizy- 
metry. Duże lizymetry cylindryczne, wyposażone w systemy ważące, są powszechnie wykorzystywane do oceny składowych naturalnego bilansu wodnego (m.in. Stumpp i in. 2007; Unold, Fank 2008; Stumpp i in. 2009b; Stumpp, Maloszewski 2010; Żurek 2010; Gebler i in. 2015), a także do charakteryzowania procesów migracji w strefie aeracji (m.in. Klier i in. 2008; Schroll i in. 2008; Wagner i in. 2008; Stumpp i in. 2009b, c; Groenendijk i in. 2014). Ogólna zasada pomiarów w lizymetrach jest następująca. Przy pomiarach składowych bilansowych analizuje się wielkość opadu, który spadł na powierzchnię lizymetru i porównuje się ją z objętością wody, która przesączyła się przez grunt wypełniający kolumnę lizymetru i odciekła do pojemników odbiorczych (Żurek 2010; Staśko, Chodacki 2014). Różnica objętości pomiędzy wielkością opadu a odciekiem jest efektem ewapotranspiracji. W przypadku lizymetrów wyposażonych w system ważący pomiary bilansowe są dodatkowo kontrolowane wahaniami ciężaru lizymetru. W doświadczeniach lizymetrycznych mających na celu ocenę procesów przepływu wody i migracji zanieczyszczeń w strefie aeracji konieczne jest wykonanie pomiarów jakościowych wody opadowej oraz wody z odcieków. W eksperymentach tych często wykorzystuje się znaczniki. Mogą to być znaczniki sztuczne trwałe, z których najczęściej stosowanym jest jon bromkowy (Stumpp i in. 2009b) oraz izotopy stabilne wody: deuter i tlen-18 (Maloszewski i in. 2006; Stumpp i in. 2007, 2009a, 2009c; Stumpp, Maloszewski 2010). Doświadczenia lizymetryczne służą także ocenie migracji substancji chemicznych stanowiących główne zanieczyszczenia wód podziemnych, takich jak np. azotany lub pestycydy (Klier i in. 2008; Schroll i in. 2008; Wagner i in. 2008; Groenendijk i in. 2014). W zaawansowanych technologicznie lizymetrach badania procesów przepływu i migracji są dodatkowo wspierane pomiarami wilgotności i siły ssącej (pomiary tensometryczne), wykonywanymi czujnikami umieszczonymi na różnych głębokościach w kolumnie lizymetru, oraz opróbowaniem zrealizowanym za pomocą sączków ulokowanych w gruncie wypełniającym lizymetr (m.in. Unold, Fank 2008).

Celem niniejszej pracy było zaprezentowanie wstępnych rezultatów badań wykorzystujących metodę penetracyjnego profilowania oporności elektrycznej dośledzenia procesu migracji znacznika w lizymetrze wypełnionym gruntem piaszczystym.

Metody badań fizycznych właściwości przypowierzchniowego ośrodka geologicznego przy pomocy specjalnych sond geofizycznych wciskanych lub wbijanych w grunt zaczęto stosować w Polsce już w latach 60. ubiegłego wieku (Borowczyk, Królikowski 1965). Z czasem gdy technika badań zaczęła uwzględniać rozwój w zakresie automatyzacji i komputeryzacji, poszerzano zakres mierzonych parametrów oraz metod interpretacji (Fejes, Josa 1990). W latach 90. w krakowskiej AGH rozwijano geoelektryczne badania penetracyjne (GBP), a szczególnie ich najprostszy wariant - penetracyjne profilowanie oporności (PPO). PPO jest przydatne w problematyce hydrogeologicznej i ochronie środowiska gruntowo-wodnego, a przykłady zastosowań zostały przedstawione w wielu pracach Antoniuka i Mościckiego 
(m.in. 1994, 1995, 1996, 1998). Dalsze prace koncentrowały się głównie na zagadnieniach metodycznych i możliwościach badania, poza opornością ośrodka, innych parametrów/zjawisk elektrycznych (Mościcki 1998a, b). Należy zaznaczyć, że badania wykorzystujące techniki penetracyjne mogą być wykonywane jedynie w ośrodkach nieskonsolidowanych, luźnych; takich jak piaski, mało zwięzłe iły, muły itp., w których może być zagłębiana sonda. Stanowi to dosyć istotne ograniczenie tej metody. Pomimo że w warunkach polskich badania geoelektryczne mają ponad półwieczną historię, to dotychczas nie były one wykorzystywane w badaniach lizymetrycznych.

\section{Opis stanowiska lizymetrycznego}

Stanowisko lizymetryczne znajduje się na terenie szkoleniowej stacji hydrologiczno-hydrogeologicznej AGH w Krakowie. W skład stanowiska wchodzą: lizymetr automatyczny z ciągłą rejestracją danych oraz trzy lizymetry „klasyczne” (fot. 1). Jest ono dodatkowo wyposażone w trzy deszczomierze różnego rodzaju oraz czujnik do pomiaru temperatury przy gruncie.

Lizymetr automatyczny ( Liz - A) został wyprodukowany przez niemiecką firmę UGT GmbH. Ma on powierzchnię $1 \mathrm{~m}^{2}$ i wysokość $1 \mathrm{~m}$. Jest on wyposażony w system ważący, urządzenie do pomiaru objętości odcieków oraz zestaw czujników do pomiaru siły ssącej, wilgotności i temperatury w gruncie wypełniającym. Lizymetry „klasyczne” (Liz I, II, III) są prostymi kolumnami ze stali nierdzewnej o głębokości 1,5 m i średnicy $0,6 \mathrm{~m}$, co daje pole powierzchni $0,283 \mathrm{~m}^{2}$ (Żurek 2010). Lizymetry zostały wypełnione piaskami średnioziarnistymi pochodzącymi z trzech różnych piaskowni. Lizymetry A i I są wypełnione takim samym piaskiem. Szczegółowa analiza składu granulometrycznego i mineralogicznego piasków wypełniających lizymetry jest przedstawiona w pracach Żurek (2010) oraz Żurek i Czopa (2010).

Lizymetry są pozbawione warstwy glebowej. Systematycznie wykonuje się pomiary objętości odcieków i wysokości opadów dla urządzeń niepodłączonych do rejestratora (lizymetry klasyczne i deszczomierz Hellmanna). Próby pobrane z opadów i odcieków są analizowane jakościowo w laboratorium hydrogeochemicznym Katedry Hydrogeologii i Geologii Inżynierskiej AGH w Krakowie.

\section{Metodyka badań}

\section{Eksperyment znacznikowy}

W celu oceny prędkości migracji zanieczyszczeń przez strefę aeracji w lizymetrze A przeprowadzono powierzchniową iniekcję znacznika trwałego - jonu bromkowego, 


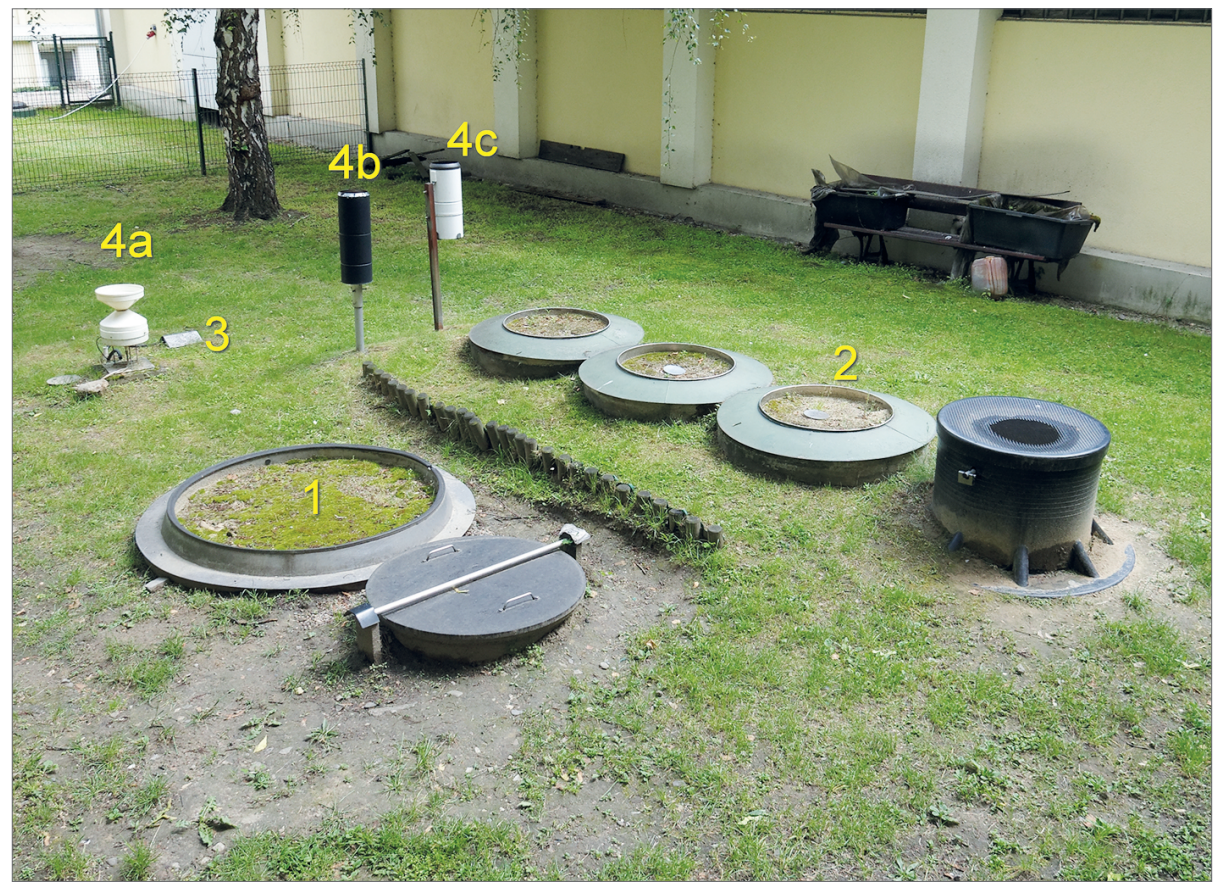

Fot. 1. Rozmieszczenie urządzeń pomiarowych na stanowisku lizymetrycznym wykorzystane w badaniach

Photo 1. Location of measuring devices at the lysimeter test sites

Objaśnienia: 1 - lizymetr automatyczny (A); 2 - lizymetr klasyczny (I); 3 - termometr przygruntowy; $4 \mathrm{a}$ - deszczomierz automatyczny, $4 \mathrm{~b}$ - deszczomierz z grzałką, 4c - deszczomierz Hellmanna.

Explanations: 1 - weighable lysimeter (A); 2 - standard lysimeter (I); 3 - near-surface thermometer; $4 \mathrm{a}$ - self-recording rain gauge; $4 \mathrm{~b}$ - self-recording rain gauge with heating; $4 \mathrm{c}-\mathrm{Hellmann}$ rain gauge. 


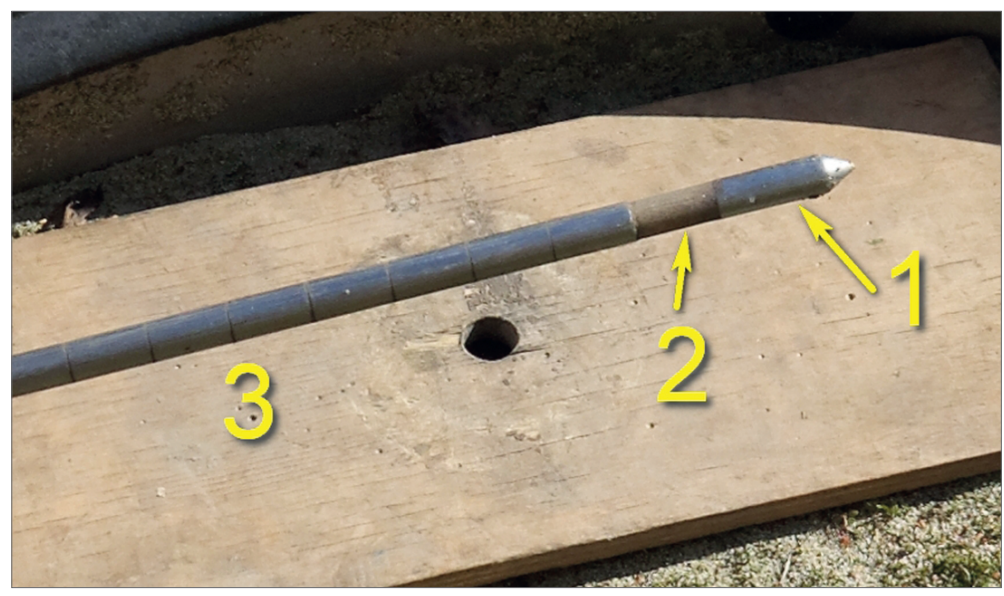

Fot. 2. Geoelektryczna, penetracyjna sonda jednoelektrodowa wykorzystywana w prezentowanych badaniach

Photo 2. Penetrometer-based single-electrode probe used in presented research

Objaśnienia: 1 - grot sondy stanowiący jednocześnie elektrodę pomiarową, 2 - izolator elektryczny, 3 - rura nośna.

Explanations: 1 - probe tip constituting the measuring electrode; 2 - electric insulator; 3 - bearing tube.

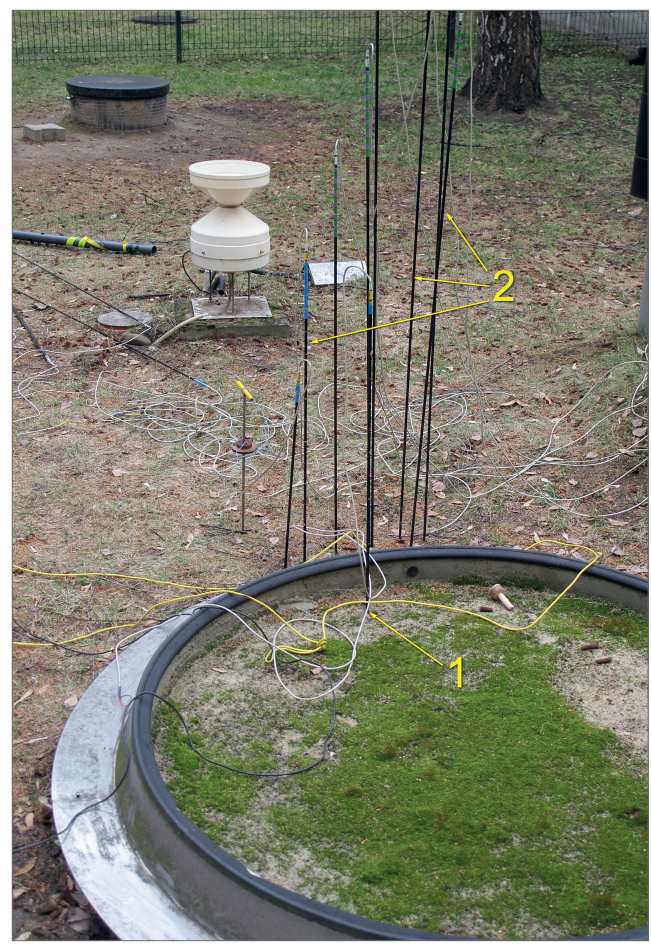

Fot. 3. Pomiary temperatury z wykorzystaniem sond termistorowych

Photo. 3 Measurements of temperature with thermistor probes

Objá́nienia: 1 - miejsce wykonywania penetracyjnego profilowanie oporności (PPO) w lizymetrze A; 2 - sondy termistorowe.

Explanations: 1 - point of resistivity profiling in lysimeter $\mathrm{A} ; 2$ - thermistor probes. 
oraz typowego zanieczyszczenia rolniczego - jonu azotanowego. Roztwór iniekcyjny przygotowano na bazie wody dejonizowanej, w której rozpuszczono odpowiednie naważki bromku potasu $(\mathrm{KBr})$ oraz azotanu wapnia $\left(\mathrm{Ca}\left(\mathrm{NO}_{3}\right)_{2}\right)$. Ostatecznie stężenia znaczników w roztworze iniekcyjnym wyniosły odpowiednio: $400 \mathrm{mgBr} \cdot \mathrm{L}^{-1}$ i $104 \mathrm{mgNO}_{3}^{-} \cdot \mathrm{L}^{-1}$ a przewodnictwo elektrolityczne właściwe (PEW) osiągnęło wartość $2100 \mu \mathrm{S} \cdot \mathrm{cm}^{-1}$, co odpowiada oporności właściwej 4,76 Wm. Iniekcji roztworu znacznikowego dokonano 3 marca 2017 r. po południu. Na powierzchni lizymetru A, wynoszącej $1 \mathrm{~m}^{2}$, rozprowadzono 41 roztworu iniekcyjnego, co odpowiada 4 mm wysokości słupa wody (ryc. 1). Oprócz standardowych obserwacji przebiegu procesu migracji obejmujących pomiary na wejściu do systemu badawczego czyli lizymetru (ilościowe i jakościowe pomiary opadów) oraz na wyjściu z niego (pomiary odcieków z lizymetru), do monitorowania procesu przemieszczania się znacznika w gruncie wypełniającym lizymetr wykorzystano badania geoelektryczne w wariancie penetracyjnego profilowania oporności (PPO). Szczegółowy opis metodyki badań PPO jest przedstawiony w następnym rozdziale. Profilowanie oporności zostało przeprowadzone trzykrotnie: bezpośrednio przed iniekcją (3.03.2017); 1 tydzień po iniekcji (10.03.2017) i 3 tygodnie po iniekcji (25.03.2017). Równocześnie z pomiarami w lizymetrze A wykonano 'reperowe' badania PPO w lizymetrze I wypełnionym takim samym gruntem, co lizymetr A. Lizymetr I ma większą głębokość niż lizymetr A $(1,5 \mathrm{~m})$ i ponad trzykrotnie mniejszą powierzchnię. Pomiary oporności wykonywano do dna lizymetrów, w odległości około $15 \mathrm{~cm}$ od ich krawędzi (fot. 2 i 3). Badania PPO wykonane w dniach 10 i 25 marca 2017 r. zostały dodatkowo uzupełnione o profilowanie temperatury gruntu w bezpośrednim sąsiedztwie lizymetru A oraz o pomiary temperatury przy dnie lizymetru. Pomiary te miały na celu uwzględnienie potencjalnego wpływu temperatury na wielkość mierzonej oporności. Ponieważ grunty wypełniające lizymetry są homogeniczne, a wody opadowe infiltrujące w głąb są bardzo nisko zmineralizowane i ich mineralizacja jest mało zmienna w czasie (Żurek i in. 2013), to wahania oporności w warunkach naturalnych, nie zaburzonych iniekcją znacznika, zależą głównie od wilgotności gruntu. Rozkład wilgotności w profilu pionowym zależy od wielkości i rozkładu opadów w okresie poprzedzającym i dlatego dla potrzeb interpretacji uzyskanych wyników pomiarów geoelektrycznych przeanalizowano rozkład opadów dobowych w okresie od 20 lutego do 30 marca 2017 r. (ryc. 1).

\section{Badania geoelektryczne}

W elektrooporowym profilowaniu penetracyjnym wykorzystano metodę wyznaczania oporności elektrycznej ośrodka geologicznego na podstawie pomiaru tzw. oporu uziemienia sondy jednoelektrodowej. Technika tego pomiaru jest następująca. Na końcu grubościennej rurki o średnicy $1 \mathrm{~cm}$, wykonanej z hartowanej stali nierdzewnej, 


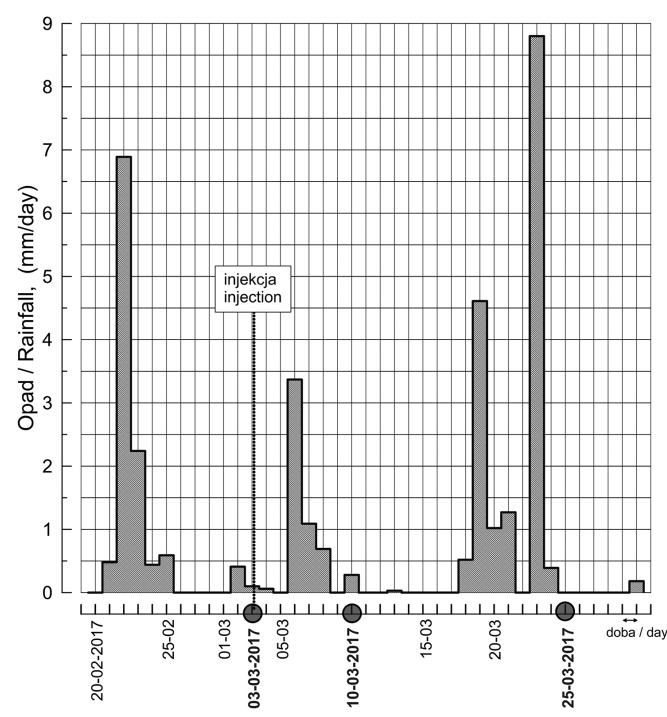

Ryc. 1. Rozkład wysokości opadów dobowych $\left[\mathrm{mm} \cdot \mathrm{d}^{-1}\right]$ w okresie realizacji pomiarów geoelektrycznych (20.02.-30.03.2017). Na wykresie zaznaczono moment iniekcji roztworu znacznikowego oraz daty pomiarów geoelektrycznych

Fig. 1. Distribution of daily rainfall $\left[\mathrm{mm} \cdot \mathrm{d}^{-1}\right]$ during geoelectrical measurements (20.02.-30.03.2017). On the graph the moment of tracer injection and the dates of geoelectrical measurements are marked umieszczony jest stalowy grot o długości ok. 2,5 cm (walec ze stożkowym szpicem). Jest on odizolowany elektrycznie od reszty rurki dystansem ceramicznym o dł. ok. $2 \mathrm{~cm}$ (fot. 2). W czasie badań grot pełni funkcję elektrody, przez którą przepływa prąd doprowadzany kablem biegnącym wewnątrz rurki nośnej do przyrządu pomiarowego (mostek Wheatstone'a). W miejscu badań umieszcza się też w gruncie dodatkową, pomocniczą elektrodę o dużej powierzchni (czyli o możliwie jak najmniejszym oporze uziemienia). Po wbiciu sondy w grunt mierzony jest sumaryczny opór elektryczny uziemienia elektrody sondy i uziemienia pomocniczego. Pomiar powtarza się dla kolejnych poziomów głębokościowych w miarę wbijania sondy. Opór uziemienia elektrody zmienia się zależnie od zmian właściwości ośrodka z głębokością, natomiast opór nieruchomego uziemienia pomocniczego pozostaje praktycznie stały (i może być wyznaczony na drodze dodatkowych pomiarów). Ponieważ elektroda sondy jest wcześniej wykalibrowana w znanych warunkach (w ośrodku o znanej oporności właściwej) to można przeliczać wartości pomierzonego oporu uziemienia elektrody pomiarowej na wartości oporności właściwej badanego ośrodka. Trzeba jednak pamiętać o tym, że są to wartości szacunkowe, ponieważ wprowadzenie sondy do ośrodka powoduje zaburzenie jego struktury i zmianę właściwości w bezpośrednim sąsiedztwie elektrody. W prezentowanych badaniach krok głębokościowy pomiaru w lizymetrach wynosił $2 \mathrm{~cm}$.

W trakcie badań w lizymetrach kolejne serie pomiarowe wykonywane były w tych samych otworach/lokalizacjach, które pozostały po pierwszym pomiarze. Pomimo że wylot otworu na powierzchnię lizymetru po każdej serii pomiarowej był zabezpieczony zaślepką, to mogło to spowodować pewne problemy z zapewnieniem 
powtarzalności warunków pomiarowych (między innymi dokładnej kontroli położenia sondy pomiarowej). Związane jest to z deformacjami ośrodka powodowanymi przez wbijaną sondę i wynikającą z tego zmianą warunków początkowych, istniejących przed pierwszym pomiarem. Zdaniem autorów zrealizowane pomiary należy traktować jako pilotażowe, a otrzymane wyniki jako obiecujące rezultaty wstępne, stwarzające podstawy do kontynuacji badań i rozwoju techniki pomiarowej.

\section{Pomiary temperatury}

Jako czujniki temperatury wykorzystano termistory (USSENSOR, PS502J2, $5 \mathrm{kOhm}$ ) o dokładności bezwzględnej $\pm 0,1^{\circ} \mathrm{C}$ i rozdzielczości $0,01^{\circ} \mathrm{C}$, osadzone w rurkach o średnicy $5 \mathrm{~mm}$ wykonanych z włókna węglowego, określanych dalej jako sondy termistorowe. Sondy te były indywidualnie wykalibrowane, tak że odchyłki pomiędzy nimi nie przekraczały $0,05^{\circ} \mathrm{C}$. Sondy instalowano w otworach o odpowiednich głębokościach wykonanych w gruncie, w bezpośrednim sąsiedztwie lizymetru A, za pomocą stalowego pręta o średnicy ok. $7 \mathrm{~mm}$ (fot. 3). Pomiary oporu termistorów wykonywano po 30 min od momentu zainstalowania sond, zakładając, że warunki termiczne, zaburzone wykonaniem otworu, były już po tym okresie ustabilizowane. Temperaturę w gruncie zmierzono także przy dnie lizymetrów wykorzystując otwory po pomiarach PPO. Pomierzone wartości oporu termistorów dla wszystkich sond zostały przeliczone na wartości temperatury przy pomocy indywidualnych tabel kalibracyjnych.

\section{Wyniki badań i dyskusja}

Uzyskane wyniki pomiarów zaprezentowano na ryc. 2. W uznanym za reperowy lizymetrze I (ryc. 2a) zmienność oporności w profilu gruntowym dla wszystkich trzech pomiarów wykazuje jedynie niewielkie zróżnicowanie do głębokości $60 \mathrm{~cm}$ ppt. Poniżej tej głębokości wykresy oporności w zasadzie się pokrywają. Pozwala to wnioskować, że wpływ wielkości i rozkładu opadów deszczu w okresie poprzedzającym pomiary na profil wilgotnościowy zaznaczył się jedynie w warstwie przypowierzchniowej. Rozkład opadów w okresie pomiarowym (ryc. 1) wskazuje, że najwyższe opady dobowe zanotowano w okresie bezpośrednio przed pomiarem zrealizowanym 25 marca 2017 r., najniższe natomiast przed pomiarem wykonanym 3 marca 2017 r. Niewielką zmienność wilgotności gruntu na głębokości $50 \mathrm{~cm}$ dla wszystkich trzech pomiarów wykazał czujnik FDR (frequency domain reflectometry), zainstalowany w lizymetrze A (ryc. 2b), z którego odczyty są rejestrowane co godzinę. Wilgotność objętościowa $(\theta)$ zarejestrowana w godzinie wykonywania pomiarów wyniosła odpowiednio: 8,9\% (3.03.2017); 9,8\% (10.03.2017); 10,6\% (25.03.2017). Zróżnicowanie to jest niewielkie i można je częściowo powiązać z rozkładem opa- 


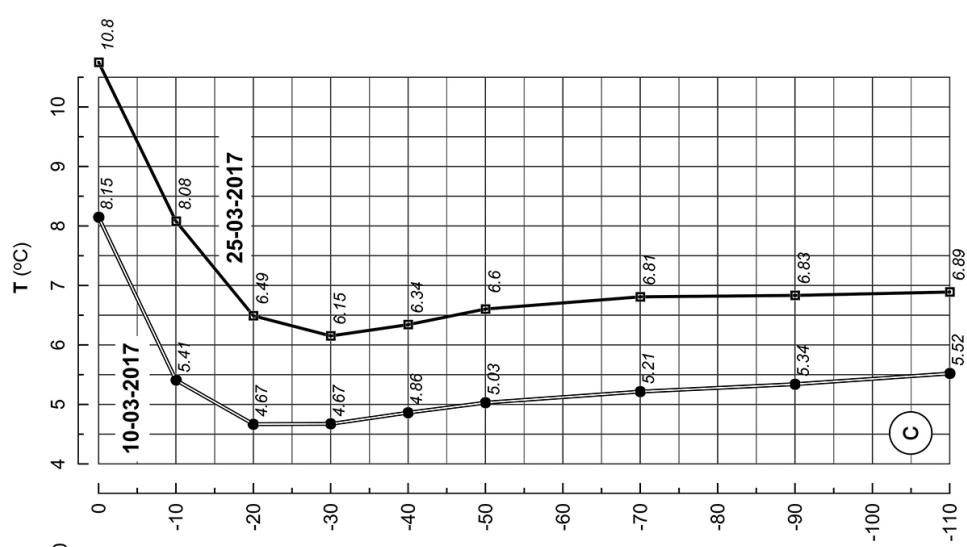

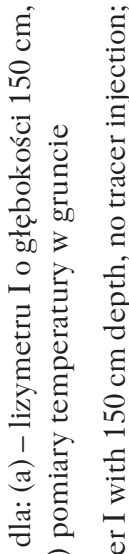

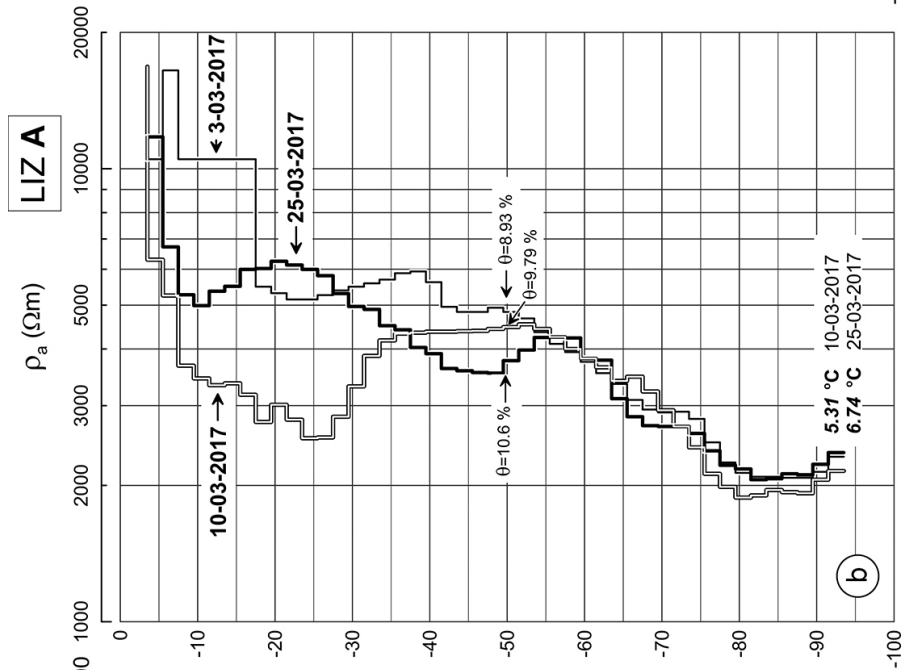

Оิ)

요유

है

范

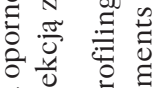

范苛范

必宓

它苛

苛氙

怘

品苞

हु

용

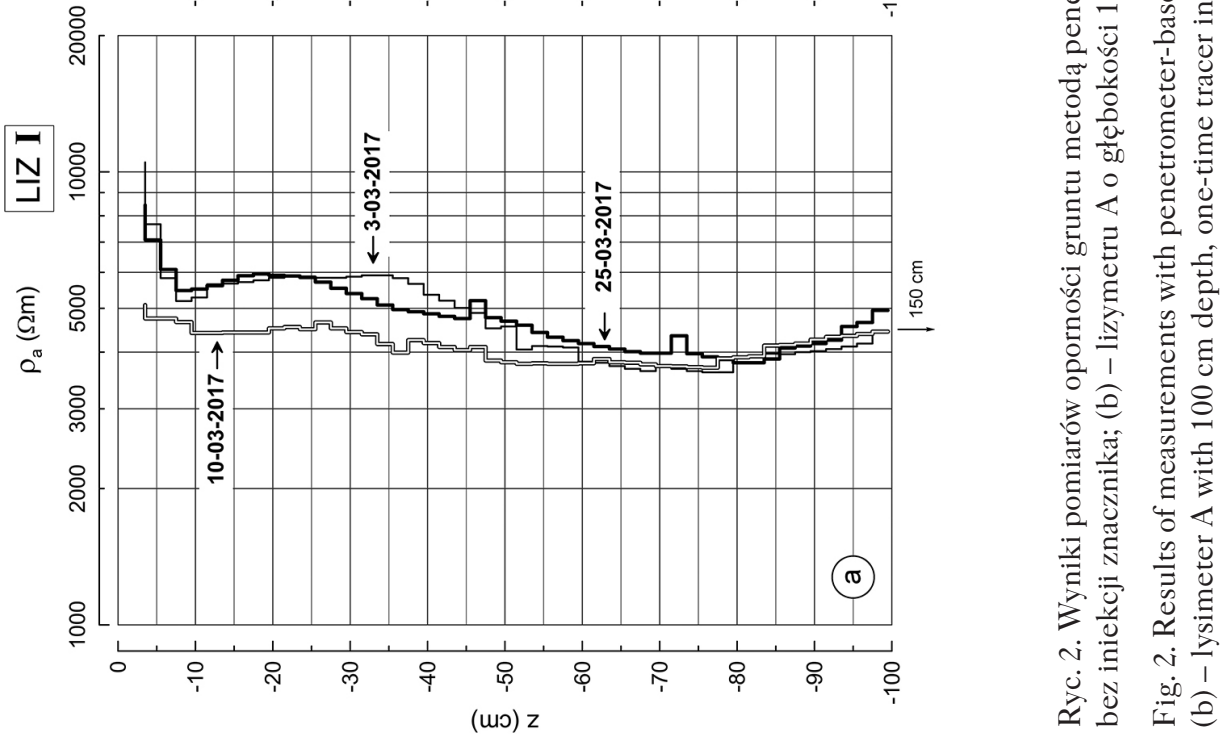


dów w tym okresie, przy czym w lizymetrze A należy także uwzględnić potencjalny wpływ 'sztucznego opadu' - równego 4 mm - w dniu iniekcji znacznika (ryc. 1).

Profile oporności pomierzone w lizymetrze A wykazały, zgodnie z oczekiwaniami, zdecydowanie większe zróżnicowanie (ryc. 2b) niż te uzyskane dla lizymetru I. Rozkład oporności gruntu w lizymetrze A dla pomiaru wykonanego bezpośrednio przed iniekcją (3.03.2017) jest do głębokości około $60 \mathrm{~cm}$ porównywalny z rozkładem w lizymetrze I. Pomiary wykonane do głębokości $20 \mathrm{~cm}$ nie podlegają interpretacji, gdyż uzyskane wartości oporności są efektem problemów technicznych związanych ze słabym i niestabilnym kontaktem sondy pomiarowej z gruntem. Poniżej głębokości $60 \mathrm{~cm}$ oporność gruntu w lizymetrze A wyraźnie spadała i była bardzo podobna dla wszystkich trzech serii pomiarowych. Ten wyraźny, gwałtowniejszy spadek oporności w porównaniu z lizymetrem I należy wiązać z mniejszą głębokością $(100 \mathrm{~cm}$ ) lizymetru A. W lizymetrach grawitacyjnych, do których należą wszystkie lizymetry z poletka badawczego, przy dnie tworzy się strefa wzniosu kapilarnego, która dla piasków średnioziarnistych wynosi około $10 \mathrm{~cm}$. Wysokość tej strefy została potwierdzona w trakcie opróbowania wykonanego dla potrzeb wcześniejszych doświadczeń znacznikowych (Zurek i in. 2014). Grunt przy dnie lizymetru ma wilgotność bliską nasyceniu, a im dalej od dna, tym ilość wilgoci jest mniejsza. Tendencja ta zanika do głębokości $60 \mathrm{~cm}$ poniżej powierzchni gruntu.

Krzywe opornościowe uzyskane pomiarami z 10 i 25 marca 2017 r., odpowiednio po 7 i 22 dobach od iniekcji, mają kształty zbliżone do klasycznych krzywych przejścia znacznika dla iniekcji chwilowej (Fetter 1999; Zuber 2007; Leibundgut i in. 2009). Coraz bardziej spłaszczone kształty krzywych przejścia pokazują rozmycie stężenia znacznika w czasie. Krzywa uzyskana dla późniejszego pomiaru (25.03.2017) jest bardziej asymetryczna i ma dłuższy tzw. 'ogon'. Maksymalne stężenia znacznika, którym odpowiadają najniższe oporności, wystąpiły odpowiednio: na głębokości ok. $25 \mathrm{~cm}$ po 7 dobach od iniekcji i $47 \mathrm{~cm}$ po 22 dobach od iniekcji. Oznacza to, że maksimum krzywej przejścia przemieściło się w strefie aeracji na odległość $22 \mathrm{~cm}$ w ciągu 15 dni. Wynika z tego, że średni czas przejścia znacznika przez kolumnę gruntu w lizymetrze A wynosi ok. 65 dni. Ten szacunkowy czas przejścia jest porównywalny z wartościami uzyskanymi na podstawie analizy stężeń znacznika w wodzie odciekającej z lizymetru we wcześniej zrealizowanych eksperymentach znacznikowych (Zurek i in. 2014).

Przedstawione na ryc. 2c profile temperaturowe są w zasadzie równoległe i przesunięte względem siebie o $2,5^{\circ} \mathrm{C}$. Taki kształt tych profili wyniknął prawdopodobnie $\mathrm{z}$ niewielkiego zróżnicowania temperatur średniodobowych w okresie pomiarowym oraz mało istotnych wahań temperatury w ciągu doby. Pomiary temperatury w profilu gruntowym towarzyszące profilowaniu opornościowemu w lizymetrach wykazały jej niewielką zmienność i pozwoliły na zaniedbanie jej wpływu na wyznaczone wartości oporności gruntu. 


\section{Podsumowanie i wnioski}

Rozpoznanie przebiegu procesów przepływu wody i migracji zanieczyszczeń w strefie aeracji ma istotne znaczenie dla oceny zasobów wód podziemnych w aspekcie ilościowym i jakościowym. Modelami fizycznymi strefy aeracji są duże lizymetry, a dla celów rozpoznania procesów przepływu i migracji powszechnie wykorzystuje się metody znacznikowe. Dla celów monitorowania procesów przemieszczania się znaczników w gruncie wypełniającym kolumnę lizymetru analizuje się stężenia znacznika w wodzie odciekowej, a w bardziej zaawansowanych technologicznie lizymetrach także w wodzie pobranej z różnych głębokości profilu gruntowego za pomocą sączków.

Zaproponowany w artykule sposób monitorowania procesów przemieszczania się zanieczyszczeń w gruncie wykorzystuje technikę penetracyjnego profilowania oporności elektrycznej. Pomysł ten wykorzystuje dwa fakty. Pierwszy, że woda opadowa infiltrująca w grunt strefy aeracji jest z reguły wodą ultrasłodką o bardzo niskiej mineralizacji, co skutkuje jej wysoką opornością elektryczną. Drugi, że roztwory iniekcyjne (ewentualnie zanieczyszczenia) charakteryzują się znacznie podwyższoną mineralizacją, która powoduje ich niską oporność. W ośrodku należy więc oczekiwać pojawienia się znacznego zróżnicowania opornościowego (kontrastu) towarzyszącego filtracji znacznika. Przeprowadzony eksperyment pozwolił oszacować, zaproponowaną metodą, prędkość migracji znacznika w gruncie piaszczystym wypełniającym lizymetr znajdujący się na stanowisku badawczym Katedry Hydrogeologii i Geologii Inżynierskiej AGH w Krakowie.

Uzyskane wstępne wyniki badań są bardzo obiecujące - oszacowany czas przesączania jest zbliżony do czasów uzyskanych we wcześniejszych, bardziej klasycznych eksperymentach znacznikowych. Obecnie prowadzone są prace nad doskonaleniem techniki powtarzalnego zagłębiania sondy, jak i samego pomiaru elektrooporowego. Planowana jest dalsza kontynuacja badań z wykorzystaniem roztworu o wyższym stężeniu.

\section{Podziękowania}

Niniejsze opracowanie zostało wykonane w ramach prac statutowych Akademii Górniczo-Hutniczej w Krakowie (projekt nr 11.11.140.797 i 11.11.140.465).

\section{Literatura}

Antoniuk J., Mościcki W.J., 1994, Metoda penetracyjnego profilowania oporności elektrycznej przyktady zastosowań, Przegląd Geologiczny, 42 (10), 857-862.

Antoniuk J., Mościcki W.J., 1995, Zastosowanie penetracyjnego profilowania oporności elektrycznej w badaniach hydrogeologicznych, [w:] J. Szczepańska, R. Kulma, A. Szczepański (red.), Wspótczesne problemy hydrogeologii, 7 (2), Krynica, 221-229. 
Antoniuk J., Mościcki W.J., 1996, Geoelektryczne badania penetracyjne dla potrzeb hydrogeologicznych, [w:] W. Ciężkowski (red.) Problemy hydrogeologicwne potudniowo-zachodniej Polski, 4, Wrocław, 239-247.

Antoniuk J., Mościcki W.J., 1998, Geoelektryczne badania penetracyjne w rozpoznawaniu środowiska hydrogeologicznego, [w:] J. Liszkowski (red.), Wspótcæesne Problemy Geologii Inżynierskiej w Polsce, WIND - J. Wojewoda, Wrocław, 77-82.

Borowczyk M., Królikowski C., 1965, Sonda uniwersalna do pomiaru własności fizycznych gruntu, Archiwum Hydrotechniki, 12 (2), 147-168.

Fejes I., Josa E., 1990, The Engineering Geophysical Sounding Method: Principles, Instrumentation, and Computerized Interpretation, [w:] S.H. Ward (red.), Geotechnical and Environmental Geophysics, Investigation in Geophysics No.5, Society of Exploration Geophysicists, Tulsa OK, 321-332.

Fetter C.W., 1999, Contaminant Hydrogeology. Second Edition, Prentice Hall, New York.

Gebler S., Hendricks Franssen H.-J., Pütz T., Post H., Schmidt M., Vereecken H., 2015, Actual evapotranspiration and precipitation measured by lysimeters: A comparison with eddy covariance and tipping bucket, Hydrology and Earth System Sciences, 19, 2145-2161.

Groenendijk P., Heinen M., Klammler G., Fank J., Kupfersberger H., 2014, Performance assessment of nitrate leaching models for highly vulnerable soils used in low-input farming based on lysimeter data, Science of the Total Environment, 499, 463-480.

Klier C., Grundmann S., Gayler S., Priesack E., 2008, Modelling the Environmental Fate of the Herbicide Glyphosate in Soil Lysimeters, Water Air Soil Pollut: Focus, 8, 187-207.

Leibundgut C., Maloszewski P., Külls C., 2009, Tracers in hydrology, Wiley-Blackwell, Sussex.

Maloszewski P., Maciejewski S., Stumpp C., Stichler W., Trimborn T., Klotz D., 2006, Modelling of water flow through typical Bavarian soils based on lysimeter experiments: 2 environmental deuterium transport, Hydrology Sciences Journal 51, 298-313.

Mościcki J., 1998a, Efekty elektrochemiczne w geoelektrycznych badaniach penetracyjnych, [w:] J. Liszkowski (red.), Wspótczesne problemy geologii inżynierskiej w Polsce, WIND J. Wojewoda, Wrocław, 273-279.

Mościcki J., 1998b, Geoelektryczne badania penetracyjne - rozpoznawanie budowy $i$ wtaściwości ośrodka geologicznego, Kwartalnik Akademii Górniczo-Hutniczej im. Stanisława Staszica w Krakowie, Geologia, 24 (2), 137-149.

Schroll R., Grundmann S., Dörfler U., Ruth B., Munch J.C., 2008, Lysimeter Experiments to Investigate the Fate of Chemicals in Soils - Comparison of Five Different Lysimeter Systems, Water Air Soil Pollut: Focus, 8, 209-216.

Staśko S., Chodacki M., 2014, Infiltracja do wód podziemnych na podstawie pomiarów lizymetrycznych w Górach Sowich, Przegląd Geologiczny, 62 (8), 414-419.

Stumpp C., Maloszewski P., 2010, Quantification of preferential flow and flow heterogeneities in an unsaturated soil planted with different crops using the environmental isotope d180, Journal of Hydrology, 394, 407-415. 
Stumpp C., Maloszewski P., Stichler W., Maciejewski S., 2007, Quantification of the heterogeneity of the unsaturated sone based on environmental deuterium observed in lysimeter experiments, Hydrological Sciences Journal, 52 (4), 748-762.

Stumpp C., Maloszewski P., Stichler W., Fank J., 2009a, Environmental isotope (d180) and hydrological data to assess water flow in unsaturated soils planted with different crops: Case study lysimeter station "Wagna" (Austria), Journal of Hydrology, 369, 198-208.

Stumpp C., Nützmann G., Maciejewski S., Maloszewski P., 2009b, A comparative modeling study of a dual tracer experiment in a large lysimeter under atmospheric conditions, Journal of Hydrology, 375, 566-577.

Stumpp C., Stichler W., Maloszewski P., 2009c, Application of the environmental isotope 1180 to study water flow in unsaturated soils planted with different crops: Case study of a weighable lysimeter from the research field in Neuherberg, Germany, Journal of Hydrology, 368, 68-78.

Szymkiewicz A., 2013, Modelling Water Flow in Unsaturated Porous Media. Accounting for Nonlinear Permeability and Material Heterogeneity, Geoplanet: Earth and Planetary Sciences, Springer, Berlin-Heidelberg.

Unold G. von Fank J., 2008, Modular Design of Field Lysimeters for Specific Application Needs, Water Air, \& Soil Pollution: Focus, 8, 233-242.

Wagner T., Arango Isaza L.M., Grundmann S., Dörfler U., Schroll R., Schloter M., Hartmann A., Sandermann H., Ernst D., 2008, The Probability of a Horizontal Gene Transfer from Roundup Ready® Soybean to Root Symbiotic Bacteria: A Risk Assessment Study on the GSF Lysimeter Station, Water Air Soil Pollut: Focus, 8, 155-162.

Zuber A. (red.), 2007, Metody snacznikowe w badaniach hydrogeologicznych. Poradnik metodyczny, Oficyna Wydawnicza Politechniki Wrocławskiej, Wrocław.

Zurek A., Witczak S., Maloszewski P., 2014, Estimation of flow and pollutant transport processes in unsaturated zone using multi-tracer experiment in a lysimeter study in Krakow, Poland, GENESIS Final Conference: Integrated Management of Groundwater Resources and Groundwater Dependent Ecosystems, 5-7 March 2014 Prague, Czech Republic, Conference Proceedings, 1118.

Zurek A., 2010, Wstepna ocena sktadowych naturalnego bilansu wodnego na podstawie obserwacji w lizymetrach, Przegląd Geologiczny, 58, 1192-1197.

Żurek A., Czop M., 2010, Modelowanie warunków præeptywu i przeks:tatceń składu chemicznego wód opadowych w trakcie procesu infiltracji, na przykładzie doświadczenia lizymetrycznego, Biuletyn Państwowego Instytutu Geologicznego, 442, 181-188.

Żurek A., Kasprzak A., Motyka J., 2013, Sewonowa zmienność ładunku azotu w wodach opadowych na terenie Krakowa, Biuletyn Państwowego Instytutu Geologicznego, 456, 693-699.

Anna J. Żurek, Wtodzimierz J. Mościcki

AGH - Akademia Górniczo-Hutnicza w Krakowie

Wydziat Geologii, Geofizyki i Ochrony Środowiska,

al. Mickiewicza 30, 30-059 Kraków

zurek@agh.edu.pl; moscicki@agh.edu.pl 